\title{
Effects of GDF-9 and FSH on mRNA Expression for FSH-R, GDF-9 and BMPs in in vitro Cultured Goat Preantral Follicles
}

\author{
Cintia Camurça Fernandes Leitão ${ }^{1}$, José Jackson do Nascimento Costa ${ }^{1 *}$, Ivina Rocha \\ Brito $^{2}$, Déborah de Melo Magalhães-Padilha ${ }^{2}$, Anderson Pinto Almeida ${ }^{2}$, José Ricardo de \\ Figueiredo $^{2}$, Robert van den Hurk ${ }^{3}$ and José Roberto Viana Silva ${ }^{1}$ \\ ${ }^{I}$ Núcleo de Biotecnologia de Sobral; Universidade Federal do Ceará; Sobral - CE - Brasil. ${ }^{2}$ Laboratório de \\ Manipulação de Oócitos Inclusos em Folículos Pré-antrais; Universidade Estadual do Ceará; Fortaleza - CE - \\ Brasil. ${ }^{3}$ Department of Pathobiology; Utrecht University; Utrecht - Netherlands
}

\begin{abstract}
The aim of the present study was to determine the role of GDF-9 and/or FSH on the growth and mRNA expression for FSH-R, GDF-9, and BMPs in goat secondary follicles after culture in vitro. Goat secondary follicles ( 200 $\mu m)$ were isolated and cultured for six days in minimum essential medium (MEM) supplemented with GDF-9 (200 $\mathrm{ng} / \mathrm{mL}), \mathrm{FSH}(50 \mathrm{ng} / \mathrm{mL})$ or both. At the beginning and end of culture, the follicular diameter was evaluated and compared. The levels of mRNA for GDF-9, FSH-R and BMPs -2, -4, -6, -7 and -15 in cultured follicles were quantified by real time PCR. The results showed that a significant increase of follicle diameter after six days when compared to day 0, but the presence of GDF-9 and FSH did not influence the follicular growth in comparison with those cultured in MEM. Real time PCR showed that GDF-9 down-regulated the levels of mRNA for BMPs -2 and 15, while FSH either alone or in combination with GDF-9 did not affect the expression of GDF-9, FSH-R and $B M P$ s. In conclusion, GDF-9 reduced the expression of BMP-2 and -15 in caprine preantral follicles after their culture, but FSH either alone or in association with GDF-9 did not control the expression of GDF-9, FSH-R and BMPs.
\end{abstract}

Key words: BMPs, follicles, GDF-9, in vitro, mRNA

\section{INTRODUCTION}

The mammalian ovary contains thousands of oocytes enclosed in preantral follicles (i.e. primordial, primary and secondary follicles) that have the potential to be fertilized, but the vast majority becomes atretic during the growth and maturation (Markström et al. 2002). To increase the efficiency of this gonad, the role of growth factors and gonadotropins that are involved in the complex bidirectional signaling between the oocyte and the surrounding somatic cells during the growth and development of secondary follicles $(\sim 200 \mu \mathrm{m})$ up to the antral stage, has been evaluated (Romero and Smitz 2009; Duarte et al. 2010;Magalhães et al. 2010). Oocyte maturation and in vitro embryo production have been described after culture of goat secondary follicles (Magalhães et al. 2010; Saraiva et al. 2010), but despite the success of these studies, these in vitro systems still have a very low efficiency, with a small percentage of embryos produced from in vitro matured oocytes. In this context, quantification of mRNA of growth factors during

\footnotetext{
*Author for correspondence: jackson.costa@hotmail.com
} 
follicular development in vitro can contribute to the establishment of an ideal culture medium and thus increase the potential of these in vitro models. Growth and differentiation factor-9 (GDF-9) belongs to the various growth factors that control the early follicle growth in mammals (Vitt and Hsueh 2002). GDF-9 may be secreted by oocyte and granulosa cells (Silva et al. 2004; Spicer et al. 2008), but oocyte-specific expression of GDF-9 protein has been reported (McGrath et al. 1995; Aaltonen et al. 1999; Jaatinen et al. 1999; Sadeu and Smitz 2008). In vitro, GDF-9 promotes the growth of the oocyte, proliferation of granulosa cells (Spicer et al. 2006), differentiation of thecal cells (Spicer et al. 2008) and specific cellular functions (Sadeu and Smitz 2008). Like GDF-9, bone morphogenetic proteins (BMPs) comprise another subgroup of ligands that are involved in the control of folliculogenesis (Hogan 1996; Dube et al. 1998). The expression of BMP -2, -4, -6, -7 and -15 has been demonstrated in the somatic follicular components of preantral follicles in several species (Erickson and Shimasaki 2003; Silva et al. 2004;Juengel et al. 2006; Frota et al. 2010). Receptors for GDF-9 (Silva et al. 2004) and FSH (Saraiva et al. 2010) are expressed in goat preantral follicles, but it is still not know if GDF-9 either alone or together with FSH controls the expression of FSH-R, GDF-9 and BMP -2, -4, -6, 7 and -15 .

It is hypothesized that GDF-9 could promote oocyte and granulosa cell development within goat preantral follicles and that this effect could be enhanced by the addition of FSH. Furthermore, the presence of GDF-9 and FSH in the culture medium can influence the expression of mRNA for GDF-9, FSH-R and BMP-2,-4,-6,-7 and -15 . To test this hypothesis, the effects of GDF-9 and FSH, alone or in combination, on the morphological development of 6-days cultured goat secondary follicles were investigated, while the levels of mRNA for GDF-9, FSH-R and BMP$2,-4,-6,-7$ and -15 in these follicles were quantified.

\section{MATERIALS AND METHODS}

\section{Ovaries}

Ovaries ( $\mathrm{n}=10)$ of goats (Capra hircus) were collected from a slaughterhouse and transported to the laboratory in minimal essential medium $(\alpha-$ MEM) containing antibiotics $(100 \mu \mathrm{g} / \mathrm{mL}$ penicillin and $100 \mu \mathrm{g} / \mathrm{mL}$ streptomycin) at $32^{\circ} \mathrm{C}$ for a maximum of $1 \mathrm{~h}$.

\section{Isolation and in vitro culture of goat secondary follicles}

In the laboratory, surrounding fat tissue and ligaments were stripped off from the ovaries. Ovarian cortical slices (1 to $2 \mathrm{~mm}$ in diameter) were cut from the ovarian surface using a surgical blade under sterile conditions. The ovarian cortex was subsequently placed in fragmentation medium, consisting of $\alpha$-MEM plus HEPES. Secondary follicles of approximately $200 \mu \mathrm{m}$ in diameter were visualized under a stereomicroscope (SMZ 645 Nikon, Tokyo, Japan) and manually dissected from the strips of ovarian cortex using 26 gauge (26G) needles. After isolation, follicles were transferred to $100 \mu \mathrm{L}$ drops containing fresh medium under mineral oil to further evaluate the follicular quality. Follicles with a visible oocyte, surrounded by granulosa cells, an intact basement membrane and no antral cavity were selected for culture (Fig. 1A).

For in vitro studies, after selection, follicles were individually cultured in $100 \mu \mathrm{L}$ drops of culture medium in Petri dishes $(60 \times 15 \mathrm{~mm}$, Corning, USA). Control culture medium consisted of $\alpha$ MEM (pH 7.2 - 7.4) supplemented with 3.0 $\mathrm{mg} / \mathrm{mL}$ bovine serum albumin (BSA), ITS (insulin $10 \mu \mathrm{g} / \mathrm{mL}$, transferrin $5.5 \mu \mathrm{g} / \mathrm{mL}$ and selenium 5 $\mathrm{ng} / \mathrm{mL}$ ), $2 \mathrm{mM}$ glutamine, $2 \mathrm{mM}$ hypoxantine and $50 \mu \mathrm{g} / \mathrm{mL}$ of ascorbic acid under mineral oil. For treatments, control culture medium was supplemented with $50 \mathrm{ng} / \mathrm{mL}$ of $\mathrm{FSH}\left(\mathrm{rFSH}^{\circledR}\right.$, Nanocore, Brazil), $200 \mathrm{ng} / \mathrm{mL}$ of GDF-9 (Sigma, St. Louis, USA) or both. The concentrations of FSH and GDF-9 were those that promoted the highest growth rates in in-vitro goat preantral follicles in previous studies (Matos et al. 2007; Martins et al. 2010). Fresh media was prepared and incubated for $1 \mathrm{~h}$ prior to use. For culture, the follicles were randomly chosen and incubated for six days in the incubator with $5 \% \mathrm{CO}_{2}$ in the air at $39^{\circ} \mathrm{C}$. Every alternate day, $60 \mu \mathrm{L}$ of the culture medium was replaced with fresh medium. A mean number of 30 follicles were used per treatment. The morphology and follicular diameter were assessed at the beginning and end of culture with the aid of an inverted microscope. In addition, the percentages of secondary follicles that reached antrum formation in vitro was determined.

To evaluate the effect of GDF-9, FSH and their combination on expression of mRNA of GDF-9, 
FSH-R and BMP $-2,-4,-6,-7$ and -15 in goat follicles that were cultured for a six-day period, for each treatment, three groups of eight follicles were collected at the end of the culture period, which were then stored at $-80^{\circ} \mathrm{C}$ until extraction of total RNA.

\section{Quantification of mRNA for GDF-9, FSH-R and BMPs in cultured follicles}

The isolation of total RNA was performed using Trizol plus purification kit (Invitrogen, São Paulo, Brazil). According to the manufacturer's instructions, $1.0 \mathrm{~mL}$ of Trizol solution was added to each frozen samples and the lysate was aspirated through a $20 \mathrm{G}$ needle before centrifugation at $10,000 \mathrm{~g}$ for $3 \mathrm{~min}$ at room temperature. Thereafter, all lysates were diluted 1:1 with $70 \%$ ethanol and subjected to a minicolumn. After binding of the RNA to the column, DNA digestion was performed using RNAse-free DNAse (340 Kunitz units $/ \mathrm{mL})$ at room temperature for $15 \mathrm{~min}$. After washing the column three times, the RNA was eluted with $30 \mu \mathrm{L}$ RNAse-free water. Prior to reverse transcription, the eluted RNA samples were incubated at $70^{\circ} \mathrm{C}$ for $5 \mathrm{~min}$ and chilled on ice. Reverse transcription was then performed in a total volume of $20 \mu \mathrm{L}$, which was comprised of $10 \mu \mathrm{L}$ of sample RNA,
$4.0 \mu \mathrm{L} 5 \mathrm{X}$ reverse transcriptase buffer (Invitrogen, São Paulo, Brazil), 8 units RNAseout, 150 units Superscript III reverse transcriptase, $0.036 \mathrm{U}$ random primers (Invitrogen, São Paulo, Brazil), 10 $\mathrm{mM}$ DTT, and $0.5 \mathrm{mM}$ of each dNTP. The mixture was incubated at $42^{\circ} \mathrm{C}$ for $1 \mathrm{~h}$, at $80^{\circ} \mathrm{C}$ for $5 \mathrm{~min}$, and then stored at $-20^{\circ} \mathrm{C}$. Negative controls were prepared under the same conditions, but without the inclusion of the reverse transcriptase.

The quantification of mRNA was performed using SYBR Green. The PCR reactions were composed of $1.0 \mu \mathrm{L}$ cDNA as a template in $7.5 \mu \mathrm{L}$ of SYBR Green Master Mix (PE Applied Biosystems, Foster City, CA), $5.5 \mu \mathrm{L}$ of ultra-pure water, and $0.5 \mu \mathrm{M}$ of each primer. The primers were designed to perform the amplification of mRNA for GDF-9, FSH-R, BMP -2, -4, -6, -7 and -15 and housekeeping genes $\beta$-actin and ubiquitin (Table 1). The thermal cycling profile for the first round of PCR was initial denaturation and activation of the polymerase at $94^{\circ} \mathrm{C}$ for $15 \mathrm{~min}$, followed by 40 cycles of $15 \mathrm{sec}$ at $94^{\circ} \mathrm{C}, 30 \mathrm{sec}$ at $60^{\circ} \mathrm{C}$, and 45 sec at $72^{\circ} \mathrm{C}$. The final extension was at $72^{\circ} \mathrm{C}$ for 10 min. All reactions were performed in a real time PCR Mastercycler (Eppendorf, Germany). The delta-delta-CT method was used to transform the CT values into normalized relative expression levels (Livak and Schmittgen 2001).

Table 1 - Primer pairs used in real-time PCR for quantification of GDF-9, FSH-R and BMPs in 6-days cultured caprine preantral follicles.

\begin{tabular}{|c|c|c|c|c|}
\hline $\begin{array}{l}\text { Target } \\
\text { gene }\end{array}$ & Primer sequence $\left(5^{\prime} \rightarrow 3^{\prime}\right)$ & $\begin{array}{c}\text { Sense (s) } \\
\text { Anti-sense (as) }\end{array}$ & Position & $\begin{array}{c}\text { Genbank } \\
\text { accession } n^{\circ} \text {. }\end{array}$ \\
\hline \multirow{2}{*}{$\beta$ - actin } & ACCACTGGCATTGTCATGGACTCT & $\mathrm{s}$ & $188-211$ & \multirow{2}{*}{ GI:28628620 } \\
\hline & $\begin{array}{l}\text { TCCTTGATGTCACGGACGATTTCC } \\
\text { GAAGATGGCCGCACTCTTCTGAT }\end{array}$ & as & $363-386$ & \\
\hline UBQ & $\begin{array}{l}\text { GAAGATGGCCGCACTCTTCTGAT } \\
\text { ATCCTGGATCTTGGCCTTCACGTT }\end{array}$ & $\mathrm{s}$ & $\begin{array}{l}607-631 \\
756-780\end{array}$ & \multirow{2}{*}{ GI:57163956 } \\
\hline \multirow{2}{*}{ GDF-9 } & ACAACACTGTTCGGCTCTTCACCC & $\mathrm{s}$ & $332-356$ & \\
\hline & CCACAACAGTAACACGATCCAGGTT & as & $426-451$ & GI:51702523 \\
\hline \multirow{2}{*}{ FSH-R } & AGGCAAATGTGTTCTCCAACCTGC & $\mathrm{s}$ & $250-274$ & \multirow{2}{*}{ GI:95768228 } \\
\hline & TGGAAGGCATCAGGGTCGATGTAT & as & $316-340$ & \\
\hline \multirow[t]{2}{*}{ BMP-2 } & $\begin{array}{l}\text { AGGCCCTTGCTTGTCACTTT } \\
\text { TTGAGGCGTTTCCGCTGTTT }\end{array}$ & $\mathrm{s}$ & 778-797 & \multirow{2}{*}{ GI: 213521327} \\
\hline & $\begin{array}{l}\text { TTGAGGCGTTTCCGCTGTTT } \\
\text { TCAACCAACCACGCCATTGT }\end{array}$ & $\begin{array}{l}\text { as } \\
\text { s }\end{array}$ & $\begin{array}{c}875-894 \\
3105-3126\end{array}$ & \\
\hline BMP-4 & TGAGTTCGGTGGGAACACAACA & as & $3191-3213$ & GI: 157092665 \\
\hline \multirow{2}{*}{ BMP-6 } & ACACATGAACGCCACCAACCAT & $\mathrm{s}$ & $141-163$ & \multirow{2}{*}{ GI:76262832 } \\
\hline & AGGATGACGTTGGAGTTGTCGT & as & & \\
\hline \multirow{2}{*}{ BMP-7 } & AGGCAGGCATGTAAGAAGCA & $\mathrm{s}$ & $78-108$ & \multirow{2}{*}{ GI: 297481859} \\
\hline & $\begin{array}{l}\text { TTGGTGGCGTTCATGTAGGA } \\
\text { A ATGGACACCTAGGGAAA }\end{array}$ & as & & \\
\hline BMP-15 & $\begin{array}{l}\text { AAGTGGACACCCTAGGGAAA } \\
\text { TTGGTATGCTACCCGGTTTGGT }\end{array}$ & $\begin{array}{c}\mathrm{S} \\
\text { as }\end{array}$ & $362-384$ & GI:8925958 \\
\hline
\end{tabular}

\section{Statistical analysis}

The nonparametric Kruskal-Wallis test was used to compare the levels of mRNA for GDF-9, FSH$\mathrm{R}, \mathrm{BMP}-2,-4,-6,-7$ and -15 in cultured follicles $(\mathrm{p}<0.05)$. The T-test was used to compare the follicular diameter before and after culture $(p<0.05)$. Data of follicular growth in the different treatments were compared by the Student- 
Newman-Keuls test $(\mathrm{p}<0.05)$. The chi-square test was used to compare the percentage of follicles that had formed an antrum $(\mathrm{p}<0.05)$.

\section{RESULTS}

\section{In vitro growth of cultured secondary follicles}

After the culture, the follicles showed a normal morphological architecture of the oocyte and neighboring granulosa cells (Fig. 1B). The secondary follicles cultured for six days in MEM alone or supplemented with FSH, GDF-9 or both
FSH and GDF-9 showed a significant increase in follicular diameter in all the treatments when compared to day 0 (Table 2). A high percentage of follicles (from 53.3 to $76.6 \%$ ) had developed an antrum cavity after the culture (Table 2 ). In these follicles, two distinct granulosa cell populations were clearly recognizable, with the cumulus cells that surrounded the oocyte being clearly distinguishable from the mural granulosa cells (Fig. 1B). However, the supplementation of culture medium with GDF-9, FSH or both did not influence either follicular growth or antrum formation (Table 2).
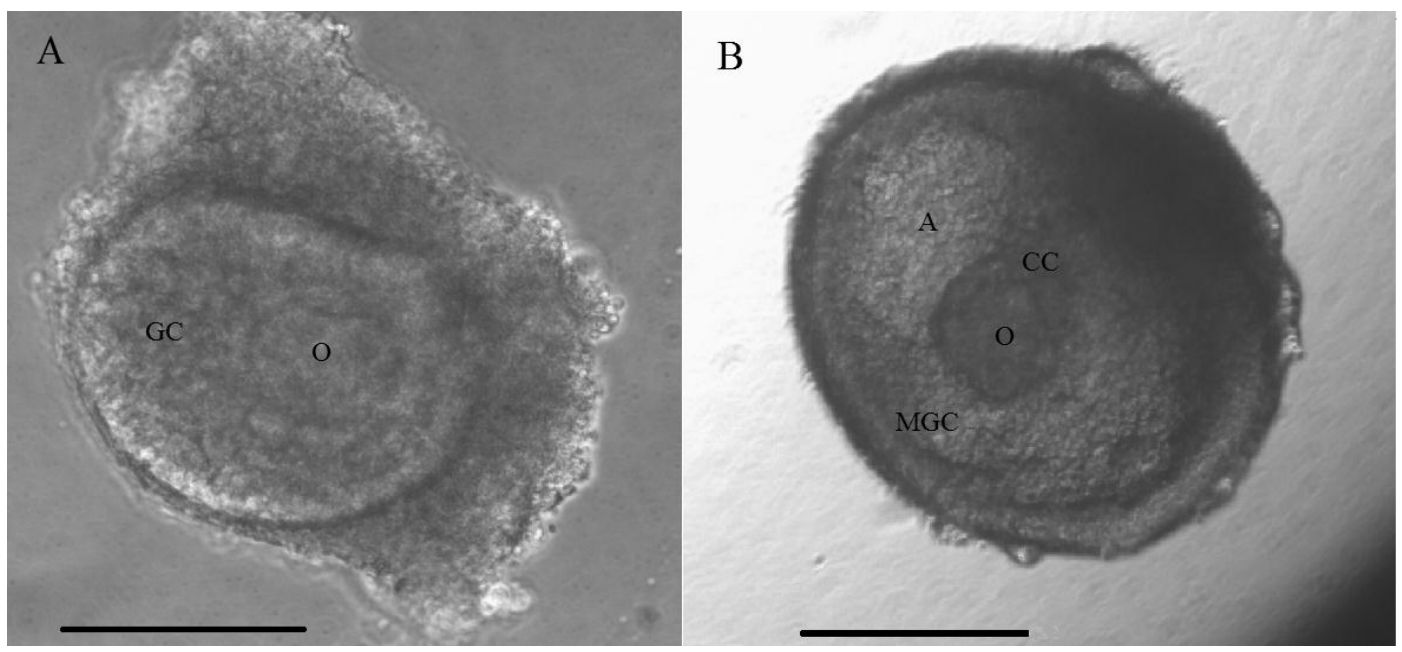

Figure 1 - Morphological characteristics of goat prantral follicles before (A) and after culture (B). A: antrum, CC: cumulus cells, GC: granulosa cells, MGC: mural granulosa cells, O: oocyte. Bars $=100 \mu \mathrm{m}$.

Table 2 - Follicular diameter and antrum formation before and after 6-days culture of secondary follicles in MEM and MEM supplemented with FSH, GDF-9 or both.

\begin{tabular}{lcccc}
\hline Treatments & $\begin{array}{c}\text { Day 0 } \\
\text { Diameter } \pm \text { SEM }\end{array}$ & $\begin{array}{c}\text { Day 6 } \\
\text { Diameter } \pm \text { SEM }\end{array}$ & $\begin{array}{c}\text { Growth } \\
\text { Diameter } \pm \text { SEM }\end{array}$ & $\begin{array}{c}\text { Antrum formation } \\
\text { at Day 6 }(\%)\end{array}$ \\
\hline MEM & $205.95 \pm 8.163$ & $296.089 \pm 15.069^{*}$ & $90.136 \pm 9.532$ & $53.3 \%(16 / 30)$ \\
MEM + FSH & $229.082 \pm 7.397$ & $352.551 \pm 14.013 *$ & $123.468 \pm 9.089$ & $63.3 \%(19 / 30)$ \\
MEM + GDF-9 & $221.088 \pm 9.52$ & $332.142 \pm 14.500^{*}$ & $111.053 \pm 9.320$ & $66.6 \%(20 / 30)$ \\
MEM + GDF-9 + FSH & $224.319 \pm 10.784$ & $336.053 \pm 17.418^{*}$ & $111.734 \pm 10.84$ & $76.6 \%(23 / 30)$ \\
\hline
\end{tabular}

*significant difference compared to day $0(\mathrm{p}<0.05)$.

Levels of mRNA for GDF-9, FSH-R and BMPs in cultured secondary follicles

As illustrated in Figures 2 and 3, culture of goat secondary follicles in medium supplemented with FSH, GDF-9 or both did not influence the levels of mRNA for GDF-9, compared to MEM alone (Fig. 2 ). Despite an increase in the levels of FSH-R from three to four times in follicles cultured in medium supplemented with FSH, GDF-9 or both, the differences were not considered statically significant (Fig. 3). On the other hand, when compared to MEM, the addition of GDF-9 to this medium significantly decreased the levels of mRNA for BMP-2 and BMP-15, but not those for BMP-4, -6, and -7. However, FSH either alone or in combination with GDF-9 did not affect the expression of GDF-9, FSH-R and BMPs (Fig. 4 AE). 


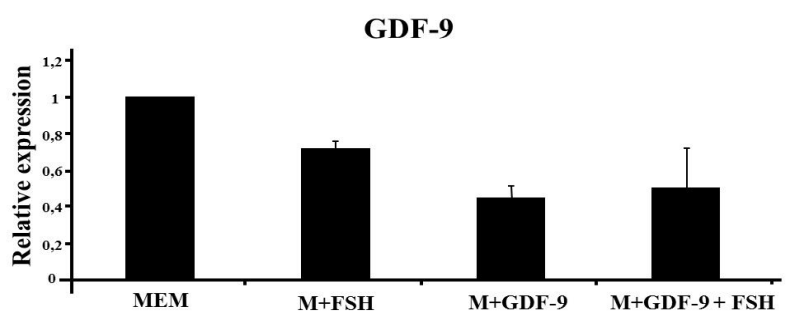

Figure 2 - Levels of mRNA for GDF-9 on goat secondary follicles after culture in MEM and MEM supplemented with FSH, GDF9 or both. (M: MEM).
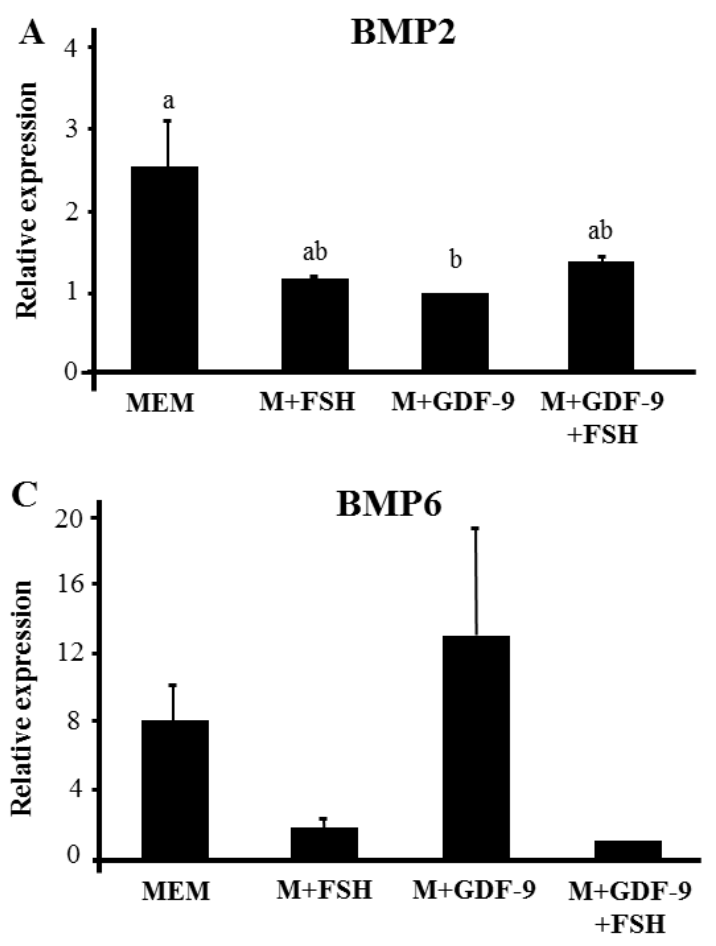

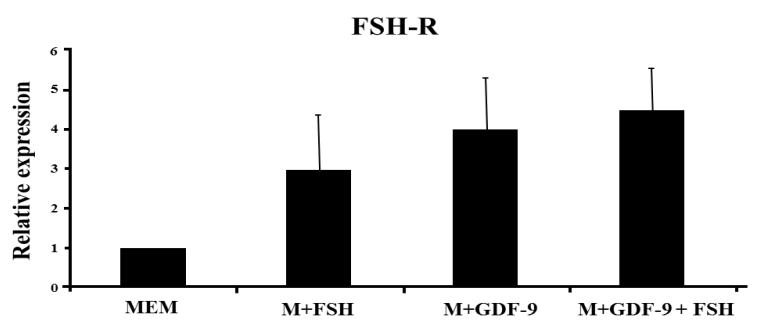

Figure 3 - Levels of mRNA for FSH-R on goat secondary follicles after culture in MEM and MEM supplemented with FSH, GDF9 or both. (M: MEM).
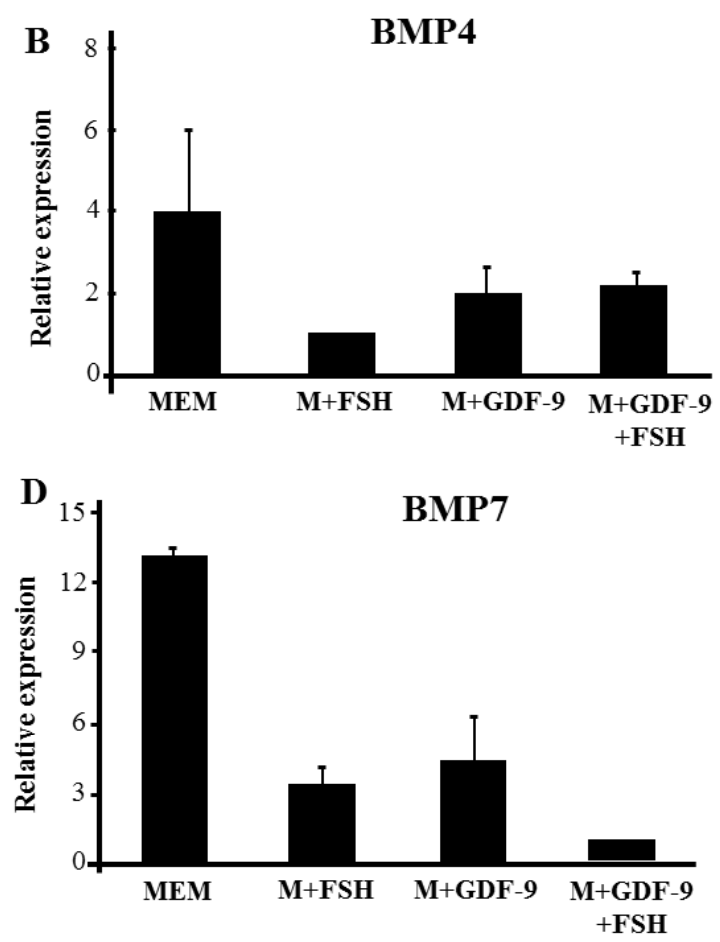

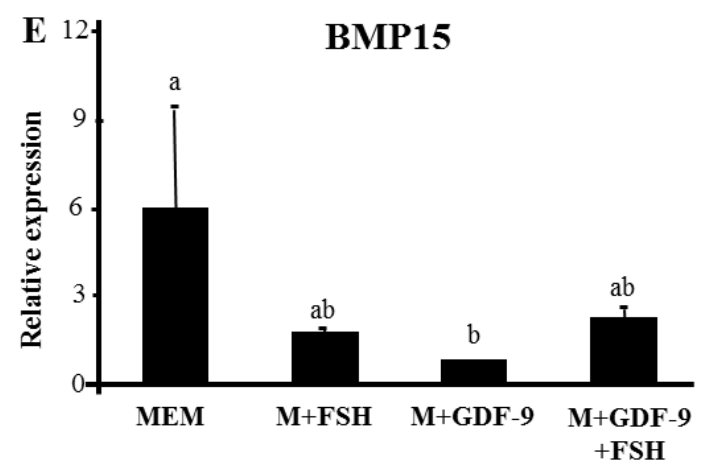

Figure 4 - Levels of mRNA for (A) BMP-2, (B) BMP-4, (C) BMP-6, (D) BMP-7 and (E) BMP-15 on goat secondary follicles after culture in MEM and MEM supplemented with FSH, GDF-9 or both. (M: MEM).

ab significant difference between treatments $(\mathrm{p}<0.05)$ 


\section{DISCUSSION}

This study demonstrated that caprine preantral follicles grew in culture, even in the absence of FSH and GDF-9. It is well established that paracrine signals from the oocyte play an essential role in the growth and development of the ovarian follicle. Oocyte-derived growth differentiation factor-9 (GDF-9) has been shown to favor the oocyte growth and follicular development (Hayashi et al. 1999; Martins et al. 2010). In this study, goat secondary follicles exposed for a period of six-day to GDF-9, FSH or both compounds, had an increase in the follicular diameter when compared to uncultured secondary follicles, but not when compared to follicles that had been cultured in MEM alone. Most likely, the absence of effects of GDF-9 and/or FSH on the development of early-staged follicles could be due to the presence insulin in control medium, a hormone which was crucial in the regulation carbohydrate and fat metabolism (Van Wezel and Rodgers 1996). Previous studies have shown that bovine preantral follicles could grow even in the absence of gonadotropins when they were cultured in the presence of insulin (Gutierrez et al. 2000) and that insulin led to enhanced cell proliferation in granulosa (Jones et al. 1995) and thecal cells (Duleba et al. 1997). This hormone is also commonly used in the cultured cells and tissues to increase the cell viability due to its ability to remove pro-apoptotic molecules and phosphatidylinositol-3 kinase activation (Louhio et al. 2000). Insulin was used successfully by Silva et al. (2010) to culture caprine preantral follicles, with the addition of a fixed concentration of FSH, which enhanced survival, growth, and development of follicles. Follicular growth may be regulated by substances produced within the follicle in response to insulin stimulation and the effects of numerous putative autocrine/paracrine follicle mediators have been discussed (van den Hurk and Zhao 2005). The presence of ascorbic acid in the medium aids in maintaining follicular viability, since it is known to promote collagen synthesis, both at the level of the genome, and as a co-factor in the secretion and stabilization of the protein (Pinnell 1985). Therefore, it is likely to assume that a follicle has a high requirement for ascorbic acid for the production of sufficient basal lamina components to maintain the expansion of this membrane during its growth.
The present findings with goat follicles showed that antrum formation was not stimulated by FSH and GDF-9 after six days of culture. The signals for antrum formation were not well understood, but several studies have shown that antrum formation was an event independent of gonadotropins (Gulyas et al. 1977; Halpin et al. 1986; Hillier et al. 1994; Cain et al. 1995). Recently, administration in culture medium of FSH did not stimulate the expression of mRNA for proteoglycans involved in antrum formation, i.e., HAS-1, HAS-2, perlecan and versican, in developing bovine follicles (Vasconcelos et al. 2012). These proteoglycans and their glycosaminoglycan side chains are osmotic solutes, which act to increase the osmotic pressure inside of the follicle, resulting in fluid accumulation (Grimek and Ax 1982; Bellin et al. 1983; Grimek et al. 1984; Clarke et al. 2006). In accordance with the present results, Vasconcelos et al. (2012) also demonstrated that the presence of GDF-9 in culture medium of bovine preantral follicles was not accompanied by an enhancement of the number of follicles showing antrum formation. The formation of antrum after culture of goat follicles even in the control medium could be due to the presence of insulin, since previous studies have shown that insulin stimulated the formation of antrum in cultured bovine preantral follicles (Itoh et al. 2002).

The results of this study showed that, in cultured secondary follicles, FSH, GDF-9 or both did not change the expression patterns of GDF-9 or FSHR. In contrast, in rodents, the expression of GDF-9 was up-regulated by FSH (Wang and Roy 2006). Contrary to FSH, the addition of GDF-9 decreased the levels of mRNA for BMP-2 and BMP-15 in cultured secondary follicles. Several studies have shown the expression of BMP-15 mRNA in primary follicles (Hogan 1996; Laitinen et al. 1998; Aaltonen et al. 1999; Jaatinen et al. 1999; Galloway et al. 2000). The mRNA for BMP-15 was previously detected in caprine primordial, primary and secondary follicles as well as in oocyte and granulosa cells of antral follicles (Silva et al. 2004). BMP-2 mRNA was localized in granulosa cells of rat primary, secondary and antral follicles (Juengel et al. 2006), as well as in theca cells of bovine antral follicles (Fatehi et al. 2005). It is possible that GDF-9 can have downregulated expression of mRNA for BMP-2 and BMP-15 either directly or indirectly, since GDF-9 is able to induce the expression of BMP 
antagonists (Pangas et al. 2004). Several highaffinity binding proteins antagonize BMP signaling, including follistatin, noggin, chordin/SOG, and members of the DAN family, including DAN, cerberus, and gremlin (Pangas et al. 2004).

\section{CONCLUSIONS}

In conclusion, this study demonstrated that the addition of GDF-9 to the culture medium of goat secondary follicles after six days in vitro reduced the synthesis of mRNA for BMP-2 and -15, but not that of BMP-4, - 6 , and -7, while FSH either alone or in combination with GDF-9 did not affect the growth and expression of GDF-9, FSH-R and BMPs in secondary follicles.

\section{ACKNOWLEDGEMENTS}

This study was supported by $\mathrm{CNPq}\left(\right.$ Grant $\mathrm{N}^{\circ} 474$ 731 / 2007-3) and FUNCAP.

\section{REFERENCES}

Aaltonen J, Laitinen MP, Vuojolainen K, Jaatinen R, Horelli-Kuitunen N, Seppa L, et al. Human growth differentiation factor 9 (GDF-9) and its novel homolog GDF-9B are expressed in oocytes during early folliculogenesis. J Clin Endocrinol Metab. 1999; 84: 2744-2250.

Bellin ME, Lenz RW, Steadman LE, Ax RL. Proteoglycan production by bovine granulosa cells in vitro occurs in response to FSH. Mol Cell Endocrinol. 1983; 29: 51-65.

Cain LS, Chatterjee A, Collins TJ. In vitro folliculogenesis of rat preantral follicles. Endocrinology. 1995; 136: 3369-3377.

Clarke HG, Hope SA, Byers S, Rodgers RJ. Formation of ovarian follicular fluid may be due to the osmotic potential of large glycosaminoglycans and proteoglycans. Reproduction. 2006; 132: 119-131.

Duarte AB, Chaves RN, Araújo VR, Celestino JJ, Silva GM, Lopes CA, et al. Follicular interactions affect the in vitro development of isolated goat preantral follicles. Zygote. 2010; 28: 1-13.

Dube JL, Wang P, Elvin J, Lyons KM, Celeste AJ, Matzuk MM. The bone morphogenetic protein 15 gene is x-linked and expressed in oocytes. Mol Endocrinol. 1998; 12: 1809-1817.
Duleba AJ, Spaczynski RZ, Olive DL, Behrman HR. Effect of insulin and insulin-like growth factors on proliferation of rat ovarian thecainterstitial cells. Biol Reprod. 1997; 56: 891-897.

Erickson GF, Shimasaki S. The spatiotemporal expression pattern of the bone morphogenetic protein family in rat ovary cell types during the estrous cycle. Reprod Biol Endocrinol. 2003; 5 1-9.

Fatehi AN, Van Den Hurk R, Colenbrander B, Daemen AJ, Van Tol HT, Monteiro RM, et al. Expression of bone morphogenetic protein 2 (BMP-2), 4 (BMP-4) and $\mathrm{BMP}$ receptors in the bovine ovary but absence of effects of BMP-2 and BMP-4 during IVM on bovine oocyte nuclear maturation and subsequent embryo development. Theriogenology. 2005; 63: 872-889.

Frota IMA, Leitão CCF, Costa JJN, Brito IR, van den Hurk R, Silva JRV. Stability of housekeeping genes and expression of locally produced growth factors and hormone receptors in goat preantral follicles. Zygote. 2010; 19: 71-83.

Galloway SM, Mcnatty KP, Cambridge LM, Laitinen MPE, Juengel JL, Jokiranta TS, et al. Mutations in an oocyte-derived growth factor gene (BMP-15) cause increased ovulation rate and infertility in a dosagesensitive manner. Nat Genet. 2000; 25: 279-283.

Grimek HJ, Ax RL. Chromatographic comparison of chondroitin-containing proteoglycan from small and large bovine ovarian follicles. Biochem Biophys Res Commun. 1982; 104: 1401-1406.

Grimek HJ, Bellin ME, Ax RL. Characteristics of proteoglycans isolated from small and large bovine ovarian follicles. Biol Reprod. 1984; 30: 397-409.

Gulyas BJ, Hodgen GD, Tullner WW, Ross GT. Effects of fetal or maternal hypophysectomy on endocrine organs and body weight in infant rhesus monkeys (Macaca mulatta): with particular emphasis on oogenesis. Biol Reprod. 1977; 16: 216-227.

Gutierrez CC, Ralph JH, Telfer EE, Wilmut I, Webb R. Growth and antral formation of bovine preantral follicles in long-term culture in vitro. Biol Reprod. 2000; 62: 1322-1328.

Halpin DM, Jones A, Fink G, Charlton HM. Postnatal ovarian follicle development in hypogonadal (HPG) and normal mice and associated changes in the hypothalamic-pituitary ovarian axis. $J$ Reprod Fertil. 1986; 77: 287-296.

Hayashi M, McGee EA, Min G, Klein C, Rose UM, Van Duin $M$, et al. Recombinant growth differentiation factor-9 (GDF-9) enhances growth and differentiation of cultured early ovarian follicles. Endocrinology. 1999; 140: 236-244.

Hillier SG. Current concepts the roles of follicle stimulating hormone and luteinizing hormone in folliculogenesis. Hum Reprod. 1994; 9: 188-191. 
Hogan BLM. Bone morphogenetic proteins: multifunctional regulators of vertebrate development. Genes Dev. 1996; 10: 1580-1594.

Itoh T, Kacchi M, Abe H, Sendai Y, Hoshi H. Growth, Antrum Formation and Estradiol Production of Bovine Preantral Follicles Cultured in a Serum-Free Medium. Biol Reprod. 2002; 67: 1099-1105.

Jaatinen R, Laitinen MP, Vuojolainen K, Aaltonen J, Louhio $\mathrm{H}$, Heikinheimo $\mathrm{K}$, et al. Localization of growth differentiation factor-9 (GDF-9) mRNA and protein in rat ovaries and cDNA cloning of rat GDF-9 and its novel homolog GDF-9B. Mol Cell Endocrinol. 1999; 156:189-193.

Jones JJ, Clemmons DR. Insulin-like growth factors and their binding proteins: biological action. Endocr Rev. 1995; 16:3-34.

Juengel JL, Reader KL, Bibby AH, Lun S, Ross I, Haydon LJ, et al. The role of bone morphogenetic proteins 2, 4, 6 and 7 during ovarian follicular development in sheep: contrast to rat. Reproduction. 2006; 131: 501-513.

Laitinen M, Vuojolainen K, Jaatinen R, Ketola I, Aaltonen J, Lehtonen E, et al. A novel growth differentiation factor-9 (GDF-9) related factor is coexpressed with GDF-9 in mouse oocytes during folliculogenesis. Mech Dev. 1998; 78: 135-140.

Livak KJ, Schmittgen TD. Analysis of relative gene expression data using real-time quantitative PCR and the ${ }^{-2 \Delta \Delta}$ CT method. Methods. 2001; 25: 402-408.

Louhio H, Hovatta O, Sjoberg J, Tuuri T. The effects of insulin and insulin-like growth factors I and II on human ovarian follicles in long-term culture. Mol Hum Reprod. 2000; 6: 694-698.

Magalhães DM, Duarte AB, Araújo VR, Brito IR, Soares TG, Lima IM, et al. In vitro production of a caprine embryo from a preantral follicle cultured in media supplemented with growth hormone. Theriogenology. 2010; 75: 182-188.

Magalhães DM, Fernandes D, Mororó M, Silva C, Rodrigues $\mathrm{G}$, Bruno $\mathrm{J}$, et al. Effect of the medium replacement interval on the viability, growth and in vitro maturation of isolated caprine and ovine preantral follicles. Reprod Domest Anim. 2010; 46: 134-140.

Markström E, Svensson EC, Shao R, Svanberg B, Billig H. Survival factors regulating ovarian apoptosisdependence on follicle differentiation. Reproduction. 2002; 123: 23-30.

Martins FS, Celestino JJ, Saraiva MV, Chaves RN, Rossetto R, Silva CM, et al. Interaction between growth differentiation factor 9, insulin-like growth factor I and growth hormone on the in vitro development and survival of goat preantral follicles. Braz J Med Biol Res. 2010; 43: 728-736.
Matos MHT, Lima-Verde IB, Bruno JB, Lopes CAP, Martins FS, Santos KDB, et al. Follicle stimulating hormone and fibroblast growth factor-2 interact and promote goat primordial follicle development in vitro. Reprod Fertil. 2007; 19: 677-684.

McGrath SA, Esquela AF, Lee SJ. Oocyte-specific expression of growth/differentiation factor-9. Mol Endocrinol. 1995; 9: 131-136.

Pangas SA, Jorgez CJ, Matzuk MM. Growth differentiation factor 9 regulates expression of the bone morphogenetic protein antagonist gremlin. $J$ Biol Chem. 2004; 279: 32281-32286.

Pinnell SR. Regulation of collagen biosynthesis by ascorbic acid: a review. Yale J Biol Med. 1985; 58: 553-559.

Romero S, Smitz J. Epiregulin can effectively mature isolated COCs, but fails as a substitute for the hCG/EGF stimulus on cultured follicles. Reproduction. 2009; 137: 997-1005.

Sadeu C, Smitz J. Growth differentiation factor-9 and anti-Müllerian hormone expression in cultured human follicles from frozen-thawed ovarian tissue. Reprod Bio Med. 2008; 17: 537-548.

Saraiva MVA, Celestino JJH, Araújo VR, Chaves RN, Almeida AP, Lima-Verde IB, et al. Expression of follicle-stimulating hormone receptor (FSHR) in goat ovarian follicles and the impact of sequential culture medium on in vitro development of caprine preantral follicles. Zygote. 2010; 21: 1-10.

Saraiva MVA, Rossetto R, Brito IR, Celestino JJ, Silva CM, Faustino LR, et al. Dynamic medium produces caprine embryo from preantral follicles grown in vitro. Reprod Sci. 2010; 17: 1135-1143.

Silva CMG, Matos MHT, Rodrigues GQ, Faustino LR, Pinto LC, Chaves RN, et al. In vitro survival and development of goat preantral follicles in two different oxygen tensions. Anim Reprod Sci. 2010; 117; 83-89.

Silva JRV, Van Den Hurk R, Van Tol HTA, Roelen BAJ, Figueiredo, J. R. Expression of growth differentiation factor-9 (GDF-9), bone morphogenetic protein 15 (BMP-15) and BMP receptors in the ovaries of goats. Mol Reprod Dev. 2004; 70; 11-19.

Spicer LJ, Aad PY, Allen D, Mazerbourg S, Hsueh AJ. Growth differentiation factor-9 has divergent effects on proliferation and steroidogenesis of bovine granulosa cells. J Endocrinol. 2006; 189: 329-339.

Spicer LJ, Aad PY, Allen DT, Mazerbourg S, Payne AH, Hsueh AJ, et al. Growth differentiation factor 9 (GDF9) stimulates proliferation and inhibits steroidogenesis by bovine theca cells: influence of follicle size on responses to GDF9. Biol Reprod. 2008; 78: 243-253. 
Van den Hurk R, Zhao J. Formation of mammalian oocytes and their growth, differentiation and maturation within ovarian follicles. Theriogenology. 2005; 63: 1717-1751.

Van Wezel I, Rodgers RJ. Morphological characterization of bovine primordial follicles and their environment in vivo. Biol Reprod. 1996; 55: 1003-1011.

Vasconcelos GL, Saraiva MVA, Costa JJN, Passos MJ, Silva AWB, Rossi RODS, et al. Effects of growth differentiation factor-9 and FSH on in vitro development, viability and mRNA expression in bovine preantral follicles. Reprod Fertil Dev. 2012; DOI: $10.1071 /$ RD12173.
Vitt UA, Hsueh AJW. Stage-dependent role of growth differentiation factor-9 in ovarian follicle development. Mol Cell Endocrinol. 2002; 186: 211217.

Wang C, Roy SK. Expression of growth differentiation factor 9 in the oocytes is essential for the development of primordial follicles in the hamster ovary. Endocrinology. 2006; 147: 1725-1734.

Received: January 17, 2013; Accepted: August 12, 2013. 